\title{
Efficiency Enhancement of Photovoltaic Module Using An Aluminum Foam Matrix Filled With Phase Change Material (PCM) Under Hot Climate Conditions
}

Mohamed Sharaf ( $\square$ mohamedsharaf2018@gmail.com )

Banha University: Benha University https://orcid.org/0000-0002-3952-0367

Mohamed S. Yousef

Benha University

Ahmed Huzayyin

Benha University

\section{Research Article}

Keywords: PV cooling, metal foam, PCM, efficiency enhancement, hot conditions

Posted Date: December 29th, 2021

DOI: https://doi.org/10.21203/rs.3.rs-1118368/v1

License: (c) (i) This work is licensed under a Creative Commons Attribution 4.0 International License.

Read Full License 


\section{Abstract}

In the present work, a passive cooling strategy combining an aluminium foam matrix (AFM) with PCM was employed to regulate the temperature of a photovoltaic (PV) system The comparison between three PV modules was established ,the first one was conventional without any changes, the second one was PV combined with PCM (PV-PCM) and the last one was PV combined with modified PCM which contain an aluminum foam matrix embedded in it (PV-PCM/AFM). Outdoor experiments were carried out in the hot weather of Benha, Egypt, which is situated at latitude $30.466^{\circ}$ North and longitude $31.185^{\circ}$ East. A comparison of the three PV designs was given and analysed, based on PV surface temperature, PCM temperature, open-circuit voltage, output power generated, and electrical efficiency. It was observed that using composite PCM resulted in better heat absorption from the PV module and better temperature distribution inside the PCM enclosure. Furthermore, the results indicated that against the unmodified PV system, the average cell's temperature in the PV-PCM system was dropped by $13.3 \%$ and its electrical power was enhanced by $9 \%$. Meanwhile, the average cell temperature in the PV-PCM/AFM configuration was reduced by $21.6 \%$ while the enhancement of the electrical power was at $14 \%$. Furthermore, the findings demonstrated that, as compared to unmodified PCM, AFM impregnation accelerated the melting of modified PCM by roughly $37 \%$.

\section{Introduction}

The global population growth and an ever-increasing need for energy due to the introduction of modern technologies are attracting greater attention (Qasim et al., 2020). Traditional electricity generation technologies, powered by fossil-based energies, are featured by high operating costs, high energy consumption, and destructive environmental effects such as climate change, ozone depletion, and greenhouse warming (Kumar et al., 2020). Therefore, to satisfy energy sustainability necessities and abate negative environmental impacts, clean and renewable energy technologies such as wind, wave, solar, tidal, geothermal, and biomass are seeing increased demand. Solar energy is the most widely used and widely recognized renewable energy source because of its cleanliness, ease of access, sustainability, and limitless potential (Xu et al., 2021). Photovoltaic (PV) technology is now one of the most appealing alternatives for increasing the percentage of renewable energy utilized, with the potential to meet about $5 \%$ of global power consumption by 2030 and $11 \%$ by 2050 . Although PV technology has a tremendous perspective, it has been hampered by its low conversion efficiency due to its elevated working temperature (Ali, 2020). As a result, to sustain a powerful electrical performance of the PV systems, it is necessary to employ an adequate cooling strategy to reduce its temperature, hence extending its lifespan. Many studies have documented a variety of thermal regulation technologies, which may be divided into two categories: passive and active cooling. Active cooling, as opposed to passive cooling, is dependent on an exterior source to maintain the fluid stream and improve heat transmission. Generally, it is more powerful than a passive scheme, but it is less cost-competent (Tan et al., 2017).

Phase-changing material (PCM) technologies have received significant interest between researchers, primarily due to its advantages over sensible heat storage materials such as higher energy density, its 
capability of storing/releasing much amount of heat with small temperature variations (isothermal nature), compactness, lower heat loss, and lower weight per unit of storage capacity. Therefore, many academics have recently focused on the merging of PV and PCM. For instance, (Waqas and Ji, 2017) explained the effects of employing PCM-packed transferrable shutters fixed at PV rear on its performance under meteorological conditions of Islamabad, Pakistan. Shutters unlocked during nocturnal hours, thereby giving a solution for PCM's partial solidification problem in the evening. PCMs with $T_{m}=30^{\circ} \mathrm{C}$ and $\mathrm{T}_{\mathrm{m}}=35^{\circ} \mathrm{C}$ demonstrated the greatest performance in January and June respectively. (Elarga et al., 2016) studied through numerical simulation the comparative performance of PV systems in double skin facades with and without PCM. Two types of paraffin wax are considered, i.e. RT55 was employed for a warm environment of Abu Dhabi whereas RT42 was employed for a cold environment of Helsinki and Venice. PCM thermally regulated PV temperature by maximum reduction of 17,20 , and $10{ }^{\circ} \mathrm{C}$, leading to electricity yield improvement of 6,8 , and $5 \%$ for Abu Dhabi, Helsinki, and Venice respectively. (Browne et al., 2016) inspected the effects of using palmitic acid/capric mixture as PCM material on the electrical performance of photovoltaic thermal PV/T configuration through outdoor experiments. Circulation of water through the heat exchanger embedded in the PV/T system was done using a thermosyphon closedloop flow approach. The results exhibited that utilization of PCM with PV/T system contributed to more than $5^{\circ} \mathrm{C}$ reductions in cell temperature as opposed to that of PV/T system in the absence of PCM. (Su et al., 2017) examined the impacts of varying the thickness and the position of the PCM on the effectiveness of air-based PV/T-PCM system. It was found that the upper PCM position exhibited overall superior performance of nearly $62 \%$ higher efficiency in comparison with the lower PCM position. Also, adding $3.4 \mathrm{~cm}$ thickness of PCM to the PV/T system gave the optimum performance with a peak PVtemperature reduction of $7.6^{\circ} \mathrm{C}$, leading to $10.7 \%$ greater overall efficiency than air-based PV/T without PCM. (Khanna et al., 2018) optimized the depth of the PCM for the thermal regulation of PV panels in several operating conditions (wind velocity, ambient temperature, solar intensity levels, and melting temperature of $\mathrm{PCM}$ ). The findings indicated that increasing the wind azimuth angle from $0^{\circ}$ to $90^{\circ}$, rising the optimal depth of the PCM layer from $3.8 \mathrm{~cm}$ to $5.2 \mathrm{~cm}$ for $4.9 \mathrm{kWh} / \mathrm{m}^{2} /$ day solar intensity. While, at the same level of solar intensity, rising the wind velocity from $1 \mathrm{~m} / \mathrm{s}$ to $4 \mathrm{~m} / \mathrm{s}$, reducing the optimal depth of the PCM layer from $4.6 \mathrm{~cm}$ to $3.5 \mathrm{~cm}$.

Despite its widespread use, PCM suffers from a severe flaw: weak thermal conductivity, which limits the efficiency of heat transfer throughout charging and discharging processes (Duan, 2021). Several techniques for heat transfer augmentation inside PCMs were accomplished by many researchers to overcome such a limitation including embedded fins, dispersion of high conductive nanoparticles, using heat pipes (HP), porous structures, encapsulation, and multiple PCMs (Xu et al., 2018). (Huang et al., 2011) explained through indoor experimentations the effectiveness of inserting fins inside a container filled with RT27 and RT35 as PCM for thermal regulation of PV modules. With increasing fins number, convection inside PCM was augmented and the time needed for complete melting was shortened. As opposed to the PV-only module, a maximum reduction (i.e. $21^{\circ} \mathrm{C}$ ) in PV temperature for the PV-PCM system is observed. (Biwole et al., 2013) explained through CFD simulation the transient performance of PV module incorporated with finned-PCM (RT25) container fixed at PV-module rear. The results revealed 
that the operating temperature of the PV panel in the absence of PCM touched $40{ }^{\circ} \mathrm{C}$ after 5 min and it retained on rising further whereas using PCM maintained the PV temperature down for 80 min at $40^{\circ}$ regulating the temperature escalation. (Rajvikram et al., 2019) proposed including an aluminum sheet above the PCM layer to act as a heat spreader. They reported that the average temperature of the cooled panel declined by $10.3{ }^{\circ} \mathrm{C}$, leading to a $24.4 \%$ improvement in electrical performance. (Sopian et al., 2020) experimentally studied in outdoor conditions the comparative performance assessment of different designs of PV/T system namely water-based PV/T, water-based PV/T with PCM, and nanofluid-based $\mathrm{PV} / \mathrm{T}$ with nano-PCM based on energy and exergy methodologies. The maximum thermal energy, thermal efficiency, and electrical exergy gained for nanofluid-based PV/T with the nano-PCM system are $13 \mathrm{~kW}$, $71 \%$, and 75.25, respectively. (Nehari et al., 2016a) numerically investigated the influence of changing fin lengths embedded in PCM (RT25) to get the optimum fin length. Heat dissipation from PCM is improved due to the presence of fins inside PCM, resulting in better PV cooling. The simulation findings revealed that fin lengths of 25,30 , and $35 \mathrm{~mm}$ were the most efficient in impeding PV-temperature escalation. In another study by the same authors (Nehari et al., 2016b), the influence of tilt angle on the effectiveness of PV system with finned PCM (RT25) at module rear for its temperature regulating is performed. They concluded that at tilt angles lesser than $45^{\circ}$, PCM was powerful because of convection dominance.

However, amongst all previous enhancement approaches, one of the most thermally efficient approaches is inserting metal porous foams in PCMs because of its many desirable properties, such as a high surface area/volume ratio, low weight, and large porosity, and high thermal conductivity. Metal foams accelerate heat transfer by expanding the surface exposed between the working fluid (PCM) and the heat source (absorber plate), resulting in improved heat transfer capability at the expense of a little reduction in heat storage capacity (Hajjar et al., 2020). As a result, several experimental and computational studies have previously demonstrated the effectiveness of embedding porous metal material inside PCMs (Chen et al., 2021), (Zheng et al., 2018), (Zhao et al., 2010), (Ghahremannezhad et al., 2020), (Dinesh and Bhattacharya, 2020), (Mancin et al., 2015), etc. They discovered that using metal porous structures improves temperature uniformity and also shortens the time required for PCM to melt. In another investigation, heat transmission of PCM-porous hybrid was observed to be 10 times higher than unmodified PCM (Duan and Li, 2021). Nevertheless, limited studies have been conducted to improve the thermal behavior of PCM by employing porous structures for PV module heat dissipation (Ahmadi et al., 2021). Temperature regulation of low concentration photovoltaic system (LCPV) comprising V-trough concentrator using paraffin wax $\left(T_{m}=56^{\circ} \mathrm{C}\right)$ with metal turnings was experimentally evaluated by (Maiti et al., 2011). By using the PCM composite, the PV temperature could be reduced up to $61^{\circ} \mathrm{C}$ and $64{ }^{\circ} \mathrm{C}$ for outdoor and indoor experiment conditions. Also, the tested system achieved about 55\% more output power compared to the non-cooled system. (Shastry and Arunachala, 2020) studied through outdoor experiments the thermal performance improvement of PCM for thermal regulation of PV system by incorporating aluminum metal matrix. The largest enhancement of $8.5 \%$ in electrical efficiency is attainable with using the proposed system compared to $3.6 \%$ for PCM-based PV/T without metal matrix, as a result of temperature drop of $11.2 \%$ and $7.8 \%$ respectively. Another solution for addressing the traditional drawback of PCM's poor thermal conductivity, (Luo et al., 2017) proposed a paraffin-based 
graphite composite having a high thermal conductivity of $(7.58 \mathrm{~W} / \mathrm{mK})$ for thermal regulation of solar panels. PV temperature declined by $24^{\circ} \mathrm{C}$ in the proposed system, was retained for a long time. The maximum improvement attained in electrical performance was 12.5\%. Recently, (Ahmadi et al., 2021) have conducted indoor experiments to examine the performance of PV panels passively and actively cooled by carbon foam embedded in PCM and passing water underneath PV, respectively, under a broad range of solar irradiance. The findings indicate that using PCM-composite as a passive cooling approach declined the PV- temperature by $6.9 \%$, which enhanced the PV electrical efficiency by $13.9 \%$. Furthermore, it was stated that the energy efficiency of the tested system with active cooling enhanced up to $81.6 \%$.

Previously published research has shown that inserting metallic porous media in PCMs enhanced the heat transfer efficiency of PCMs, allowing for more powerful temperature control of photovoltaic panels and the bulk of the majority of these investigations used numerical simulations. Although there are few studies on experimental exams, most of them were conducted in indoor situations, which may provide data that are insufficiently dependable to fully examine system performance, It is critical to do more research in outside environments.Accordingly, the key objective of the present work is to experimentally examine the performance enhancement of PV using an aluminum foam matrix (AFM) embedded in PCM, under hot climate conditions of Benha city, Egypt, located at (latitude $30.466^{\circ}$ North and longitude $31.185^{\circ}$ East). Three alternative instances were tested outdoors: PV/PCM-AMF, PV/PCM, and PV. A comparison of the three PV systems is established based on the PV cells temperature, paraffin temperature, power yield and electrical efficiency. In addition, the current study's important results are compared to those of comparable systems in the literature.

\section{Experimental Setup}

Experiments are conducted on the rooftop of the Benha College of Engineering campus to compare the performance of the proposed PV-PCM/AMF system against traditional PV and PV-PCM systems without metal foam. In this part, the experimental setup procedures are shown below: Section 2.1 describes the design of experimental setup equipment and the techniques involved in their construction, and section 2.2 explains the steps involved in the measurements. Next, the uncertainty analysis is covered in section 2.3.

\subsection{Construction of the setup}

Experiments were carried out in this study to inspect the effect of PCM added to PV panels on their performance. The test rig is represented in a photo in Fig. 1. In this setup, 20W silicon-based PV cells are employed in three diverse systems, i.e., PV-only, PV-PCM, and PV-PCM/AMF systems. The three designs' electrical and thermal evaluations were evaluated at the same time under the same weather circumstances. The characteristics of PV panels are summarised in Table 1. 
Table 1

Data sheet of the PV panel

\begin{tabular}{|ll|}
\hline PV panel & \\
\hline Model & SM-20 P \\
\hline$P_{m}$ & $20 \mathrm{~W}$ \\
\hline$V_{m p}$ & $18 \mathrm{~V}$ \\
\hline$I_{m p}$ & $1.11 \mathrm{~A}$ \\
\hline$V_{o C}$ & $21.2 \mathrm{~V}$ \\
\hline$I_{S C}$ & $1.19 \mathrm{~A}$ \\
\hline Dimensions & $49 \star 35^{\star} 1.7 \mathrm{~cm}$ \\
\hline Test environments & $1000 \mathrm{~W} / \mathrm{m}^{2} 25^{\circ} \mathrm{C}$ \\
\hline
\end{tabular}

Before starting experiments, the electrical power of identical six PV panels is tested during sunny days to ensure consistent measurements throughout the experiments. The best three panels were chosen for the main experiments depending on the results. In this setup, commercially accessible paraffin is used as a PCM owing to its favorable qualities such as cost, stability, non-corrosiveness, as well as its comparatively large enthalpy of fusion. Thus, in this research, (PCM RT 42) was chosen for use in the current work. Table 2 depicts more information regarding the features of the specified PCM. 
Table 2

Date sheet of PCM (RT42) (RUBITHERM,

n.d.)

\begin{tabular}{|ll|}
\hline Data & Values \\
\hline Storage capacity $\pm 8 \%$ & $170 \mathrm{~kJ} / \mathrm{kg}$ \\
\hline Melting point & $38-43^{\circ} \mathrm{C}$ \\
\hline Density in solid state & $0.88 \mathrm{~kg} / \mathrm{l}$ \\
\hline Congealing point & $43-37^{\circ} \mathrm{C}$ \\
\hline Density in liquid state & $0.75 \mathrm{~kg} / \mathrm{l}$ \\
\hline Flash temperature & $168^{\circ} \mathrm{C}$ \\
\hline Specific heat & $1.9 \mathrm{~kJ} / \mathrm{kg} \cdot \mathrm{K}$ \\
\hline Volume expansion & $12.5[\%]$ \\
\hline Thermal conductivity & $0.21[\mathrm{~W} /(\mathrm{m} \cdot \mathrm{K})]$ \\
\hline Maximum Temperature & $74^{\circ} \mathrm{C}$ \\
\hline
\end{tabular}

In this setup, two identical aluminum boxes have been used with dimensions of $49 \mathrm{~cm} \times 35 \mathrm{~cm} \times 3.9 \mathrm{~cm}$, one of them was placed into the bottom of the PV panel to store PCM for the PV-PCM system. Whereas the second one was used for the third system PV-PCM/AMF for the same purpose. In the beginning, to process the PCM melting, the PCM was put inside a water bath with a temperature range of $80-85^{\circ} \mathrm{C}$ which is an optimal temperature range for such kind of paraffin. Then, the process of pouring is established by streaming the melted PCM via a hole bored at the upper edge of the box. After accounting for probable volume expansion during phase change operations, about $4.4 \mathrm{~kg}$ of wax was needed to occupy the box. To prevent liquid PCM leaking, a sealant was inserted space-between the backside of the PV panel and paraffin box then adhered to screw compression. In order to overcome the weak thermal conductivity of PCM, A rectangular aluminum foam with $94 \%$ porosity and having the same size as the PCM container was inserted inside the PCM container of the PV-PCM/AMF system. In this system, around $4.18 \mathrm{~kg}$ of wax was required to occupy the box. Fig. 2 displays an image of the third system PVPCM/AMF before putting PCM. Also, Fig. 3 depicts a schematic representation of the investigated systems. To gather maximum solar irradiance, all PV configurations are installed on a platform with a south-facing $31^{\circ}$ tilt angle, corresponding to the latitude of Benha city.

\subsection{Measurements}

In this work, the temperatures of different sections of PV panels are measured using many T-type thermocouples. The front temperature of the PV panel is equivalent to the average value of three thermocouples positioned in the front of the panel. In addition, two thermocouples were used to monitor the temperature of the PV module's backside surface. In addition, two thermocouples were inserted in the 
paraffin to observe the temperature fluctuation within the PCM box, which are positioned $1.7 \mathrm{~cm}$ and 3.2 $\mathrm{cm}$ from the upper edge of the box, as shown in Fig. 4. A weather station was used to measure the environmental temperature, the intensity of solar radiation on a tilted surface, and wind velocity. The output power was monitored regularly and manually recorded for further calculations. All thermocouples were attached to a data acquisition device for data storage at five-minute intervals. The outdoor experiment was performed on the rooftop of Benha College of Engineering campus, Benha city, Egypt.

\subsection{Uncertainty analysis}

In this work, the uncertainty and error analysis is performed using the measured data as shown in Table 3. The uncertainty $\left(\delta_{q}\right)$ of computed values $(q)$ relying on measured values $\left(x_{1} x_{2}, x_{3}, \ldots\right.$ and $\left.x_{n}\right)$ from uncertainties of the testing instruments $\left(\delta_{1}, \delta_{2}, \delta_{3}, \ldots\right.$, and $\left.\delta_{n}\right)$ of measured values $\left(x_{1} x_{2}, x_{3}, \ldots\right.$ and $\left.x_{n}\right)$ is determined using the next equation (Hassan et al., 2018; Holman, 2011).

$$
\delta_{q}=\sqrt{\left(\frac{\partial u}{\partial x_{1}}\right) \delta_{x_{1}}^{2}+\left(\frac{\partial u}{\partial x_{2}}\right) \delta_{x_{2}}^{2}+\ldots+\left(\frac{\partial u}{\partial x_{n}}\right) \delta_{x_{n}}^{2}}
$$

1

As a result, the uncertainties of the observed variables in the current work are approximated as indicated in Table 3 based on several trials. The total uncertainty of the experiment employing Eq. (1) was determined to be less than $1.5 \%$, demonstrating great measurement accuracy.

Table 3

Instruments uncertainty

\begin{tabular}{|lll|}
\hline Parameter & Instrument & Uncertainty \\
\hline Solar intensity & Weather station & $+/-1 \%$ \\
\hline Temperature & Thermocouple Type T & $+/-1 \%$ \\
\hline Current & Ammeter & $+/-0.7 \%$ \\
\hline Voltage & Voltmeter & $+/-0.7 \%$ \\
\hline Data Logger & Logging measurement & $\pm 0.05 \%$ \\
\hline
\end{tabular}

\section{Results And Discussions}

The results of an investigation into the effect of employing composite PCM/AFM as a passive cooling method on photovoltaic electrical performance are presented in this section. As previously stated, a comparative analysis is conducted for three distinct situations, including PV, PV-PCM, and PV-PCM/AFM configurations, in terms of the following factors: surface temperature of the PV, PCM temperature, output power generated, and electrical efficiency. Additionally, the results of this study are compared to those of 
comparable studies published before. Finally, the cost assessment findings for the evaluated systems were presented and debated.

\subsection{Weather date}

During the day of the experiment, the changes of solar radiation and ambient temperature with regard to time were shown in Figs. 5 and 6 . As shown in Fig. 5 , the solar radiation profile throughout the day was homogeneous, and solar radiation increased throughout the day from sunrise to midday, before beginning to drop until dusk. During peak hours, the highest solar intensity of around $788 \mathrm{~W} / \mathrm{m} 2$ was reached at midday, with peak and average ambient temperatures of $39.3^{\circ} \mathrm{C}$ and $35^{\circ} \mathrm{C}$, respectively, according to Fig. 6.

\subsection{Thermal performance}

\subsubsection{PV temperatures}

$\mathrm{PV}$ temperature is an extremely significant parameter for thermal regulation of PV panels and plays a critical role in determining PV system performance. Fig. 7 shows the temperature distributions of the three PV module combinations that were under-tested. On Fig. 7, the fluctuation in ambient temperature was also overlaid. It can be observed that as the day proceeds, the PV temperatures rise in lockstep with the solar intensity temperature profiles, reaching their maximum values at midday in all cases. Then, for the remainder of the day, until dusk, the PV temperatures are on the decline. Due to the presence of PCM as a heat sink, the temperature of modified panels (PV-PCM and PV-PCM/AFM) is much lower than that of naturally cooled PV modules. Furthermore, PV temperature is lower in PV-PCM/AFM than in PV-PCM because aluminium foam with high thermal conductivity acts as a heat spreader, allowing for greater heat absorption from the PV module as compared to pure PCM. The highest temperature of conventional PV was $61^{\circ} \mathrm{C}$, compared to $51.9^{\circ} \mathrm{C}$ and $49.1^{\circ} \mathrm{C}$ for PV-PCM and PV-PCM/AFM, respectively, resulting in a $17.5 \%$ and $24.2 \%$ temperature decrease. In addition, when AFM was added to PCM, the average cell temperature dropped by $13.3 \%$ and $7.3 \%$, respectively, as compared to PV and PV-PCM systems. As a result, combining the AFM with the PCM proved to be the most efficient in avoiding PV temperature rise due to quick thermal dissipation from the PV surface.

\subsubsection{PCM temperatures}

As previously stated, two temperature thermocouples, PCM1 (upper point) and PCM2 (lower point), are placed within each PCM enclosure for PV-PCM and PV-PCM/AFM systems. Figs. 8 and 9 illustrate the equivalent temperature trends of PCM1 and PCM2 for PV and PV-PCM/AFM systems. Although two temperature sensors in each container may not be enough to fully express the temperature distribution within the PCM reservoir, they may aid in understanding the thermal behaviour of the PCM inside the container. In Fig. 8, for the PV-PCM configuration, in the morning, the temperature of PCM1 started to gradually increase and while the neighboring PCM was melting, an obvious shift was perceived at about 12:00 pm where the temperature of PCM1 approaches approximately $42{ }^{\circ} \mathrm{C}$ (melting point), signifying that the paraffin nearby the position 1 was melted. Subsequently, the temperature of PCM1 retained 
almost for one hour and afterward grew quickly to about $48^{\circ} \mathrm{C}$ at $3: 30 \mathrm{pm}$ before starting to decline. On the contrary, the temperature of PCM 2, in the beginning, increased gradually from $28.5^{\circ} \mathrm{C}$ in the morning to about $41^{\circ} \mathrm{C}$ at $12: 00 \mathrm{pm}$, followed by a plateau until 2:30 pm before its temperature grew steadily again. Such a big temperature gradient between PCM1 and PCM2 reveals that the contour of the temperature of PCM in the enclosure is not uniform, caused by the poor thermal conductivity of PCM, leading to the possible consequences of prolonged melting of PCM. On the other hand, for PV-PCM/AFM system, as depicted in Fig. 9, the temperature profile of PCM1 and PCM2 is more uniform (the curves closer to each other) comparative with pure PCM, as depicted in Figs. 8 and 9. Obviously, the incorporation of metal foam with PCM makes the PCM's temperature distribution more uniform by providing a greater contact area which potentially might dissipate the heat from PV into the PCM rapidly.

Close examination of the melting behaviour of pure PCM and modified PCM in Figs. 8 and 9 reveals that the melting of PCM with AFM is significantly faster than that of pure PCM, with the phase change occurring at 12:00 p.m.; whereas, when the AFM is incorporated into the PCM, the phase change occurs at 10:30 a.m. This indicates that the AFM leads the PCM to melt in a shorter amount of time, around 90 minutes, which is approximately $37.5 \%$ quicker than pure PCM. Additionally, it is discovered that the modified PCM's maximum temperature increased by around $4 \%$ when compared to the pure PCM's maximum temperature.

\subsection{Electrical performance}

\subsubsection{Power output}

It has long been known that the temperature of PV technologies has a detrimental impact on their electrical performance. Fig. 10 depicts the development of produced power of the conventional PV, PVPCM, and PV-PCM/AFM panels throughout the course of the test day. As can be observed, the profile of electric power follows the same fluctuation pattern as solar radiation, growing steadily throughout the first half of the day until reaching its peak at midday, before falling again during the second half of the day till sunset. PV-PCM and PV-PCM/AFM panels, as expected, provide greater electrical power than the conventional PV panel. This might be due to the heat removed by the PCM, which helps to reduce the temperature of the panels while changing their phase. In addition, it was discovered that, as compared to pure PCM, putting AFM within PCM greatly increased power output due to the higher heat dissipation benefits of PCM/AFM over pure PCM, as seen in Fig. 7. The results demonstrated that the peak electric output of the PV-PCM and PV-PCM/AFM setups was increased by $10 \%$ and $16 \%$, respectively, when compared to the unmodified PV module. In addition, the average power yield of conventional PV was 9.68 W, compared to $10.56 \mathrm{~W}$ and $11.04 \mathrm{~W}$ for PV-PCM and PV-PCM/AFM, respectively, resulting in a $9 \%$ and $14 \%$ increase in power production.

\subsubsection{Electrical efficiency}

Fig. 11 illustrates the electrical efficiency of the standard PV, PV-PCM, and PV-PCM/AFM setups over time. As can be observed, the PV electrical efficiency steadily drops over the day's first half, reaching a 
minimal value around midday. Then, for the remainder of the day, the PV electrical efficiency increases. This pattern may be attributed to the fact that the temperature of the photovoltaic panels was high around midday, resulting in a decrease in output voltage and hence a decrease in electrical efficiency. On average, the electrical efficiency of the conventional PV, PV-PCM, and PV-PCM/AFM systems was 11.62 $\%, 12.64 \%$, and $13.09 \%$, respectively. Additionally, the efficiency of the PV-PCM/AFM configuration is more consistent; the variation in value between the minimum and maximum efficiency of the PVPCM/AFM configuration is approximately $2.45 \%$, compared to $3.26 \%$ and $2.66 \%$, respectively, for the PV and PV-PCM configurations.

\subsection{Comparison with previous works}

In this section, the current study's key findings are compared to those of other investigations that have been accomplished to enhance the thermal performance of PCM using porous metal structures for thermal regulation of PV panels. As can be seen from Table 4, in all scenarios, impregnating the PCM with porous metal structures accelerated the melting time of PCM as well as led to a significant drop in PV temperature, and thus an enhancement in the PV's electrical efficiency was obtained. In terms of the melting time of PCM, (Abdelrazik et al., 2018) revealed that the PCM's melting time was shortened by approximately $28 \%$ by using a similar aluminum metal foam similar to the one used in the current study. In another study, using industrial aluminum shavings achieved about 19\%-25\% faster melting time compared to unmodified PCM. (Ebadi et al., 2020) explained through experimental examination the potential of impregnating salt hydrate PCM with a copper wire mesh; around $24 \%$ reduction in the charging time of PCM was observed. In another investigation carried out by (Hu and Gong, 2020), the thermal performance of paraffin wax was enhanced by using porous foam having a cubic structure and porosity similar to the present research. They reported that the proposed heat-dissipating technique shortened the melting rate of PCM by approximately $38 \%$. In the current study, using a composite of aluminum foam matrix impregnated with PCM as a passive cooling technique accelerated the melting time of PCM by about 90 min, which was around $37.5 \%$ faster than the pure PCM, indicating an effective performance of the current porous foam. In terms of PV-temperature reduction, the proposed cooling technique provides more than a $15^{\circ} \mathrm{C}$ drop in the PV temperature, indicating a competitive performance as a passive cooling technique compared to the other studies such as (Kumar et al., 2020; Qasim et al., 2020). Also, in the current study, it was found that the average PV electrical efficiency was enhanced by $14 \%$, which is higher than most of the improvement percentages obtained by the other systems, as indicated in Table 4. More details about the comparative performance between the current work with previous studies can be depicted in Table 4 . 
Table 4

Comparison of the findings of the present work with some investigations in the literature

\begin{tabular}{|c|c|c|c|c|}
\hline Reference & $\begin{array}{l}\text { Included } \\
\text { Medium }\end{array}$ & $\begin{array}{l}\text { PCM } \\
\text { Type }\end{array}$ & System & Key Findings \\
\hline \multirow[t]{3}{*}{$\begin{array}{l}\text { (Mousavi et al., } \\
\text { 2018) }\end{array}$} & $\begin{array}{l}\text { Copper Metal } \\
\text { Foam }\end{array}$ & Paraffin & $\mathrm{PV} / \mathrm{T}$ & $\begin{array}{l}\text { Peak thermal efficiency was } \\
83 \%\end{array}$ \\
\hline & & & & $\begin{array}{l}\text { Electrical efficiency enhanced } \\
\text { by } 4.3 \%\end{array}$ \\
\hline & & & & $\begin{array}{l}\text { Exergy efficiency enhanced by } \\
1.2 \%\end{array}$ \\
\hline \multirow[t]{3}{*}{$\begin{array}{l}\text { (Hossain et al., } \\
\text { 2019) }\end{array}$} & Foil Packets & $\begin{array}{l}\text { Lauric } \\
\text { acid }\end{array}$ & $\mathrm{PV} / \mathrm{T}$ & $\begin{array}{l}\text { Electrical efficiency enhanced } \\
\text { by } 2.1 \%\end{array}$ \\
\hline & & & & $\begin{array}{l}\text { Maximum thermal efficiency } \\
\text { was } 87.8 \%\end{array}$ \\
\hline & & & & $\begin{array}{l}\text { Average exergy efficiency was } \\
12.28 \%\end{array}$ \\
\hline \multirow[t]{3}{*}{$\begin{array}{l}\text { (Shastry and } \\
\text { Arunachala, 2020) }\end{array}$} & Metal Matrix & OM-47 & $\mathrm{PV} / \mathrm{T}$ & $\begin{array}{l}\text { PV-temperature reduction } \\
\text { improved by } 11.1 \%\end{array}$ \\
\hline & & & & $\begin{array}{l}\text { Maximum thermal efficiency } \\
\text { was } 48.5 \%\end{array}$ \\
\hline & & & & $\begin{array}{l}\text { Electrical efficiency augmented } \\
\text { by } 1.3 \%\end{array}$ \\
\hline \multirow[t]{3}{*}{ (Maiti et al., 2011) } & $\begin{array}{l}\text { Aluminum } \\
\text { Chips }\end{array}$ & Paraffin & $\begin{array}{l}\text { PV integrated } \\
\text { with V-trough }\end{array}$ & $\begin{array}{l}\text { Melting time of PCM was } \\
\text { shortened by } 70 \mathrm{~min} \text {. }\end{array}$ \\
\hline & & & & $\begin{array}{l}\text { PV-temperature fell by peak } \\
22^{\circ} \mathrm{C}\end{array}$ \\
\hline & & & & $\begin{array}{l}55 \% \text { overall output power } \\
\text { improvement. }\end{array}$ \\
\hline \multirow[t]{5}{*}{$\begin{array}{l}\text { (Vaziri Rad et al., } \\
\text { 2021) }\end{array}$} & $\begin{array}{l}\text { Aluminum } \\
\text { Shavings }\end{array}$ & $\begin{array}{l}\text { Salt } \\
\text { Hydrate }\end{array}$ & $\mathrm{PV} / \mathrm{T}$ & $\begin{array}{l}\text { Melting time of PCM was } \\
\text { shortened by } 19-25 \% \text {. }\end{array}$ \\
\hline & & & & $\begin{array}{l}\text { PV-temperature declined by } \\
20^{\circ} \mathrm{C}\end{array}$ \\
\hline & & & & $\begin{array}{l}\text { Average thermal efficiency was } \\
60.9 \%\end{array}$ \\
\hline & & & & $\begin{array}{l}\text { Electrical efficiency } \\
\text { enhancement was } 2.6 \%\end{array}$ \\
\hline & & & & $\begin{array}{l}\text { Average exergy efficiency was } \\
17.4 \%\end{array}$ \\
\hline
\end{tabular}

* The findings of the present study are described in the table compared to the conventional PV panel. 


\begin{tabular}{|c|c|c|c|c|}
\hline Reference & $\begin{array}{l}\text { Included } \\
\text { Medium }\end{array}$ & $\begin{array}{l}\text { PCM } \\
\text { Type }\end{array}$ & System & Key Findings \\
\hline $\begin{array}{l}\text { (Klemm et al., } \\
2017)\end{array}$ & Metal Fibers & $\begin{array}{l}\text { RT } 54 \\
\text { HC }\end{array}$ & PV & $\begin{array}{l}\text { PV-temperature dropped by } \\
\text { maximum } 20^{\circ} \mathrm{C}\end{array}$ \\
\hline \multirow[t]{2}{*}{$\begin{array}{l}\text { (Ahmadi et al., } \\
\text { 2021) }\end{array}$} & \multirow[t]{2}{*}{$\begin{array}{l}\text { PS-CNT } \\
\text { Foam }\end{array}$} & \multirow[t]{2}{*}{$\begin{array}{l}\text { Paraffin } \\
\text { Wax }\end{array}$} & \multirow[t]{2}{*}{$\mathrm{PV} / \mathrm{T}$} & $\begin{array}{l}\text { PV-cell temperature dropped by } \\
6.8 \%\end{array}$ \\
\hline & & & & $\begin{array}{l}\text { Electrical efficiency enhanced } \\
\text { by } 14 \%\end{array}$ \\
\hline \multirow[t]{2}{*}{ (Luo et al., 2017) } & \multirow[t]{2}{*}{$\begin{array}{l}\text { Expandable } \\
\text { graphite }\end{array}$} & \multirow[t]{2}{*}{ RT28 } & \multirow[t]{2}{*}{ PV } & $\begin{array}{l}\text { PV-cells temperature declined } \\
\text { by } 25^{\circ} \mathrm{C}\end{array}$ \\
\hline & & & & $\begin{array}{l}\text { Maximum improvement in } \\
\text { power output was } 11.4 \%\end{array}$ \\
\hline \multirow{3}{*}{$\begin{array}{l}\text { Present } \\
\text { Study * }\end{array}$} & \multirow[t]{3}{*}{$\begin{array}{l}\text { Aluminum } \\
\text { Metal Foam }\end{array}$} & \multirow[t]{3}{*}{$\begin{array}{l}\text { Paraffin } \\
\text { Wax }\end{array}$} & \multirow[t]{3}{*}{ PV } & $\begin{array}{l}\text { Melting time of PCM was } \\
\text { shortened by } 37 \%\end{array}$ \\
\hline & & & & $\begin{array}{l}\text { PV-temperature declined by } \\
15^{\circ} \mathrm{C}\end{array}$ \\
\hline & & & & $\begin{array}{l}\text { Overall output power was } \\
\text { enhanced by } 14 \%\end{array}$ \\
\hline
\end{tabular}

\section{Conclusion}

In this study, a combination of paraffin wax with AFM was added to a PV module to control its temperature and thus enhanced its electrical performance. Experiments were carried out in hot weather conditions of Benha city, Egypt, using three distinct cases: conventional PV, PV-PCM, and PV-PCM/AFM. The three systems' fluctuations in PV surface temperature, PCM temperature, open-circuit voltage, output power generated, and electrical efficiency were reported and compared. The findings indicated that against the unmodified PV system, the average cell's temperature in PV-PCM and PV-PCM/AFM systems was dropped by $13.3 \%$ and $21.6 \%$, respectively. Meanwhile, the average electrical efficiency was enhanced by $9 \%$ and $14 \%$, respectively. Also, insertion of AFM as an inexpensive porous structure inside PCM not only reduced temperature gradient but also the total melting time was shortened by $37 \%$ compared with pure PCM. The cost of electricity generation for PV-PCM and PV-PCM/AFM was 0.0824 and $0.0812 \$ / \mathrm{kWh}$, respectively, against $0.0831 \$ / \mathrm{kWh}$ for a PV system, achieving cost reduction of $1 \%$ and $2.4 \%$. Comparing the main results of the current study with those of similar systems in the literature indicated the effectiveness of the proposed system. However, by incorporating PCM/AFM into a hybrid electricity-and-heat cogeneration PV/T system, superior energy and economic possibilities might be produced. In addition, the authors want to conduct a future simulation research to investigate the influence of other PCMs with varied melting temperatures on the performance of the proposed system. 


\section{Declarations}

\section{Ethical Approval}

Not applicable.

\section{Consent to Participate}

We affirm that all authors have participated in the research work and are fully aware of ethical responsibilities.

\section{Consent to Publish}

We affirm that all authors have agreed for submission of the paper to ESPR and are fully aware of ethical responsibilities.

\section{Authors Contributions}

Author contribution is as follows:

\begin{tabular}{|ll|}
\hline Author & Contribution \\
\hline Mohamed Sharaf & Writing \\
\hline Mohamed S. Yousef & Editing - Revision \\
\hline Ahmed S. Huzayyin & Revision \\
\hline
\end{tabular}

\section{Funding}

Not applicable.

\section{Competing Interests}

Not applicable.

\section{Availability of data and materials}

Research data can be obtained from the corresponding author through email.

\section{References}

1. Abdelrazik AS, Al-Sulaiman FA, Saidur R, Ben-Mansour R (2018) A review on recent development for the design and packaging of hybrid photovoltaic/thermal (PV/T) solar systems. Renew Sustain Energy Rev 95:110-129. https://doi.org/10.1016/j.rser.2018.07.013 
2. Ahmadi R, Monadinia F, Maleki M (2021) Passive/active photovoltaic-thermal (PVT) system implementing infiltrated phase change material (PCM) in PS-CNT foam. Sol Energy Mater Sol Cells 222:110942. https://doi.org/10.1016/j.solmat.2020.110942

3. Ali HM (2020) Recent advancements in PV cooling and efficiency enhancement integrating phase change materials based systems - A comprehensive review. Sol Energy 197:163-198. https://doi.org/10.1016/j.solener.2019.11.075

4. Biwole PH, Eclache P, Kuznik F (2013) Phase-change materials to improve solar panel's performance. Energy Build 62:59-67. https://doi.org/10.1016/j.enbuild.2013.02.059

5. Browne MC, Norton B, McCormack SJ (2016) Heat retention of a photovoltaic/thermal collector with PCM. Sol Energy 133:533-548

6. Chen X, Li X, Xia X, Sun C, Liu R (2021) Thermal storage analysis of a foam-filled PCM heat exchanger subjected to fluctuating flow conditions. Energy 216:119259. https://doi.org/10.1016/j.energy.2020.119259

7. Dinesh BVS, Bhattacharya A (2020) Comparison of energy absorption characteristics of PCM-metal foam systems with different pore size distributions. J Energy Storage 28:101190. https://doi.org/10.1016/j.est.2019.101190

8. Duan J (2021) A novel heat sink for cooling concentrator photovoltaic system using PCM-porous system. Appl Therm Eng 186:116522

9. Duan J, Li F (2021) Transient heat transfer analysis of phase change material melting in metal foam by experimental study and artificial neural network. J Energy Storage 33:102160. https://doi.org/10.1016/j.est.2020.102160

10. Ebadi S, Tasnim SH, Aliabadi AA, Mahmud S (2020) An experimental investigation of the charging process of thermal energy storage system filled with PCM and metal wire mesh. Appl Therm Eng 174:115266. https://doi.org/10.1016/j.applthermaleng.2020.115266

11. Elarga H, Goia F, Zarrella A, Dal Monte A, Benini E (2016) Thermal and electrical performance of an integrated PV-PCM system in double skin façades: A numerical study. Sol Energy 136:112-124. https://doi.org/10.1016/j.solener.2016.06.074

12. Ghahremannezhad A, Xu H, Salimpour MR, Wang P, Vafai K (2020) Thermal performance analysis of phase change materials (PCMs) embedded in gradient porous metal foams. Appl Therm Eng 179:115731. https://doi.org/10.1016/j.applthermaleng.2020.115731

13. Hajjar A, Jamesahar E, Shirivand H, Ghalambaz M, Babaei Mahani R (2020) Transient phase change heat transfer in a metal foam-phase change material heatsink subject to a pulse heat flux. J Energy Storage 31:101701. https://doi.org/10.1016/j.est.2020.101701

14. Hassan H, Ahmed MS, Fathy M (2018) Experimental Work on the Effect of Saline Water Medium on the Performance of Solar Still with Tracked Parabolic Trough Collector (TPTC). Renew Energy. https://doi.org/10.1016/j.renene.2018.11.112

15. Holman JP (2011) Experimental Methods for Engineers. McGraw-Hill, 
16. Hossain MS, Pandey AK, Selvaraj J, Rahim NA, Islam MM, Tyagi VV (2019) Two side serpentine flow based photovoltaic-thermal-phase change materials (PVT-PCM) system: Energy, exergy and economic analysis. Renew Energy 136:1320-1336. https://doi.org/10.1016/j.renene.2018.10.097

17. Hu X, Gong X (2020) Experimental and numerical investigation on thermal performance enhancement of phase change material embedding porous metal structure with cubic cell. Appl Therm Eng 175:115337. https://doi.org/10.1016/j.applthermaleng.2020.115337

18. Huang MJ, Eames PC, Norton B, Hewitt NJ (2011) Natural convection in an internally finned phase change material heat sink for the thermal management of photovoltaics. Sol Energy Mater Sol Cells 95:1598-1603. https://doi.org/10.1016/j.solmat.2011.01.008

19. Khanna S, Reddy KS, Mallick TK (2018) Optimization of finned solar photovoltaic phase change material (finned pv pcm) system. Int J Therm Sci 130:313-322. https://doi.org/10.1016/j.jthermalsci.2018.04.033

20. Klemm T, Hassabou A, Abdallah A, Andersen O (2017) Thermal energy storage with phase change materials to increase the efficiency of solar photovoltaic modules. Energy Procedia 135:193-202

21. Kumar R, Praveen P, Gupta S, Saikiran J, Bharj RS (2020) Performance evaluation of photovoltaic module integrated with phase change material-filled container with external fins for extremely hot climates. J Energy Storage 32:101876

22. Luo Z, Huang Z, Xie N, Gao X, Xu T, Fang Y, Zhang Z (2017) Numerical and experimental study on temperature control of solar panels with form-stable paraffin/expanded graphite composite PCM. Energy Convers Manag 149:416-423. https://doi.org/10.1016/j.enconman.2017.07.046

23. Maiti S, Banerjee S, Vyas K, Patel P, Ghosh PK (2011) Self regulation of photovoltaic module temperature in V-trough using a metal-wax composite phase change matrix. Sol Energy 85:18051816. https://doi.org/10.1016/j.solener.2011.04.021

24. Mancin S, Diani A, Doretti L, Hooman K, Rossetto L (2015) Experimental analysis of phase change phenomenon of paraffin waxes embedded in copper foams. Int J Therm Sci 90:79-89. https://doi.org/10.1016/j.jthermalsci.2014.11.023

25. Mousavi S, Kasaeian A, Behshad M (2018) Numerical investigation of the eff ects of a copper foam fi lled with phase change materials in a water-cooled photovoltaic / thermal system. 163:187-195. https://doi.org/10.1016/j.enconman.2018.02.039

26. Nehari T, Benlakam M, Nehari D (2016a) Effect of the Fins Length for the Passive Cooling of the Photovoltaic Panels. https://doi.org/10.3311/PPme.8571

27. Nehari T, Benlekkam M, Nehari D (2016b) The Effect of Inclination on the Passive cooling of the solar PV panel by using Phase change Material 6

28. Qasim MA, Ali HM, Khan MN, Arshad N, Khaliq D, Ali Z, Janjua MM (2020) The effect of using hybrid phase change materials on thermal management of photovoltaic panels-An experimental study. Sol Energy 209:415-423

29. Rajvikram M, Leoponraj S, Ramkumar S, Akshaya H, Dheeraj A (2019) Experimental investigation on the abasement of operating temperature in solar photovoltaic panel using PCM and aluminium. Sol 
Energy 188:327-338

30. RUBITHERM, n.d. RUBITHERM [WWW Document]. URL www.RUBITHERM.com

31. Shastry DMC, Arunachala UC (2020) Thermal management of photovoltaic module with metal matrix embedded PCM. J Energy Storage 28:101312. https://doi.org/10.1016/j.est.2020.101312

32. Sopian K, Al-Waeli AHA, Kazem HA (2020) Energy, exergy and efficiency of four photovoltaic thermal collectors with different energy storage material. J Energy Storage 29:101245. https://doi.org/10.1016/j.est.2020.101245

33. Su D, Jia Y, Alva G, Liu L, Fang G (2017) Comparative analyses on dynamic performances of photovoltaic-thermal solar collectors integrated with phase change materials. Energy Convers Manag 131:79-89. https://doi.org/10.1016/j.enconman.2016.11.002

34. Tan L, Date A, Fernandes G, Singh B, Ganguly S (2017) Efficiency Gains of Photovoltaic System Using Latent Heat Thermal Energy Storage. Energy Procedia 110:83-88. https://doi.org/10.1016/j.egypro.2017.03.110

35. Vaziri Rad MA, Kasaeian A, Mousavi S, Rajaee F, Kouravand A (2021) Empirical investigation of a photovoltaic-thermal system with phase change materials and aluminum shavings porous media. Renew Energy 167:662-675. https://doi.org/10.1016/j.renene.2020.11.135

36. Waqas A, Ji J (2017) Thermal management of conventional PV panel using PCM with movable shutters - A numerical study. Sol Energy 158:797-807.

https://doi.org/10.1016/j.solener.2017.10.050

37. Xu H, Wang N, Zhang C, Qu Z, Karimi F (2021) Energy conversion performance of a PV/T-PCM system under different thermal regulation strategies. Energy Convers Manag 229:113660. https://doi.org/10.1016/j.enconman.2020.113660

38. Xu Y, Li MJ, Zheng ZJ, Xue XD (2018) Melting performance enhancement of phase change material by a limited amount of metal foam: Configurational optimization and economic assessment. Appl Energy 212:868-880. https://doi.org/10.1016/j.apenergy.2017.12.082

39. Zhao CY, Lu W, Tian Y (2010) Heat transfer enhancement for thermal energy storage using metal foams embedded within phase change materials (PCMs). Sol Energy 84:1402-1412. https://doi.org/10.1016/j.solener.2010.04.022

40. Zheng H, Wang C, Liu Q, Tian Z, Fan X (2018) Thermal performance of copper foam/paraffin composite phase change material. Energy Convers Manag 157:372-381. https://doi.org/10.1016/j.enconman.2017.12.023

\section{Figures}




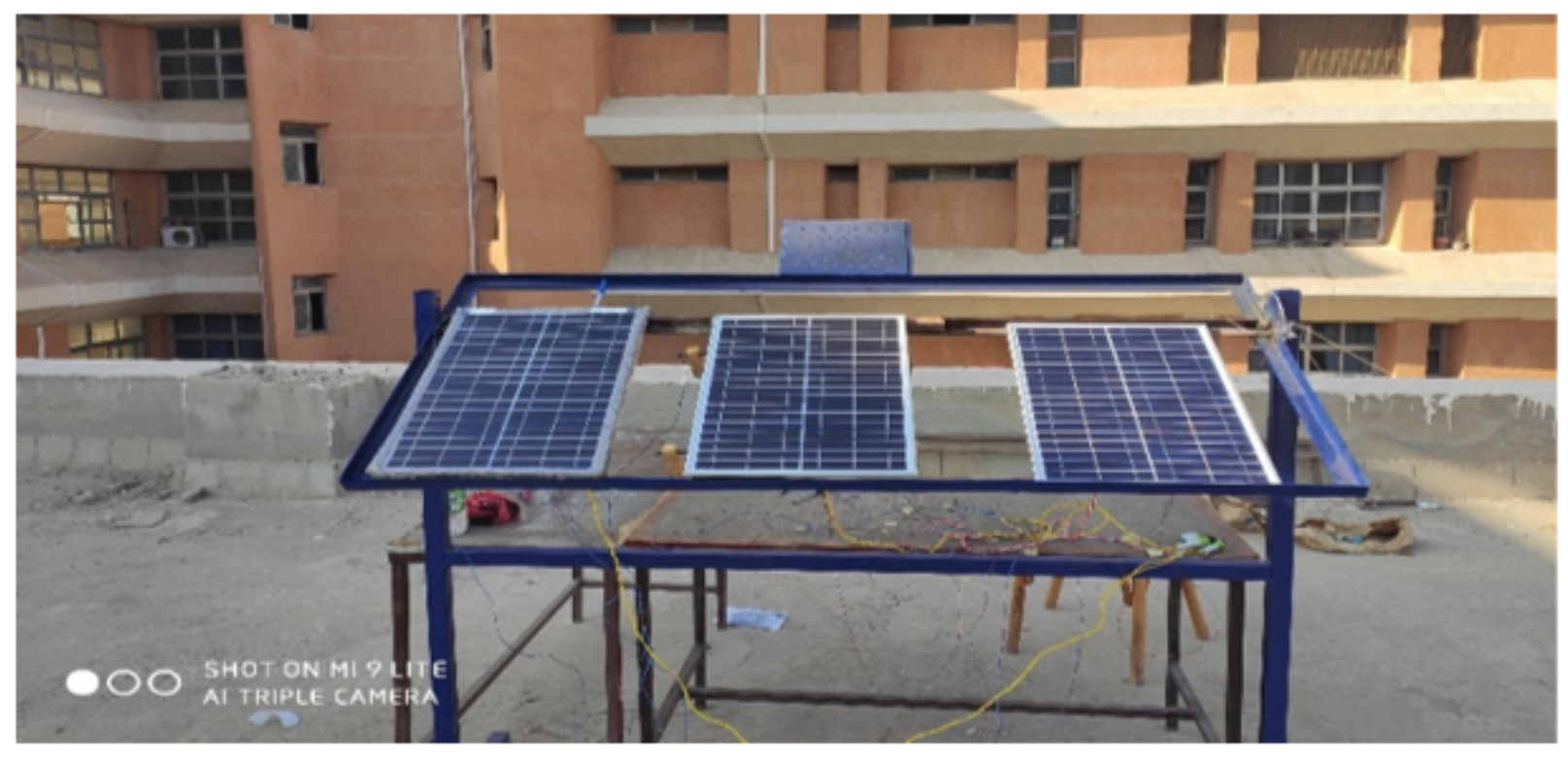

Figure 1

An image of the test rig.

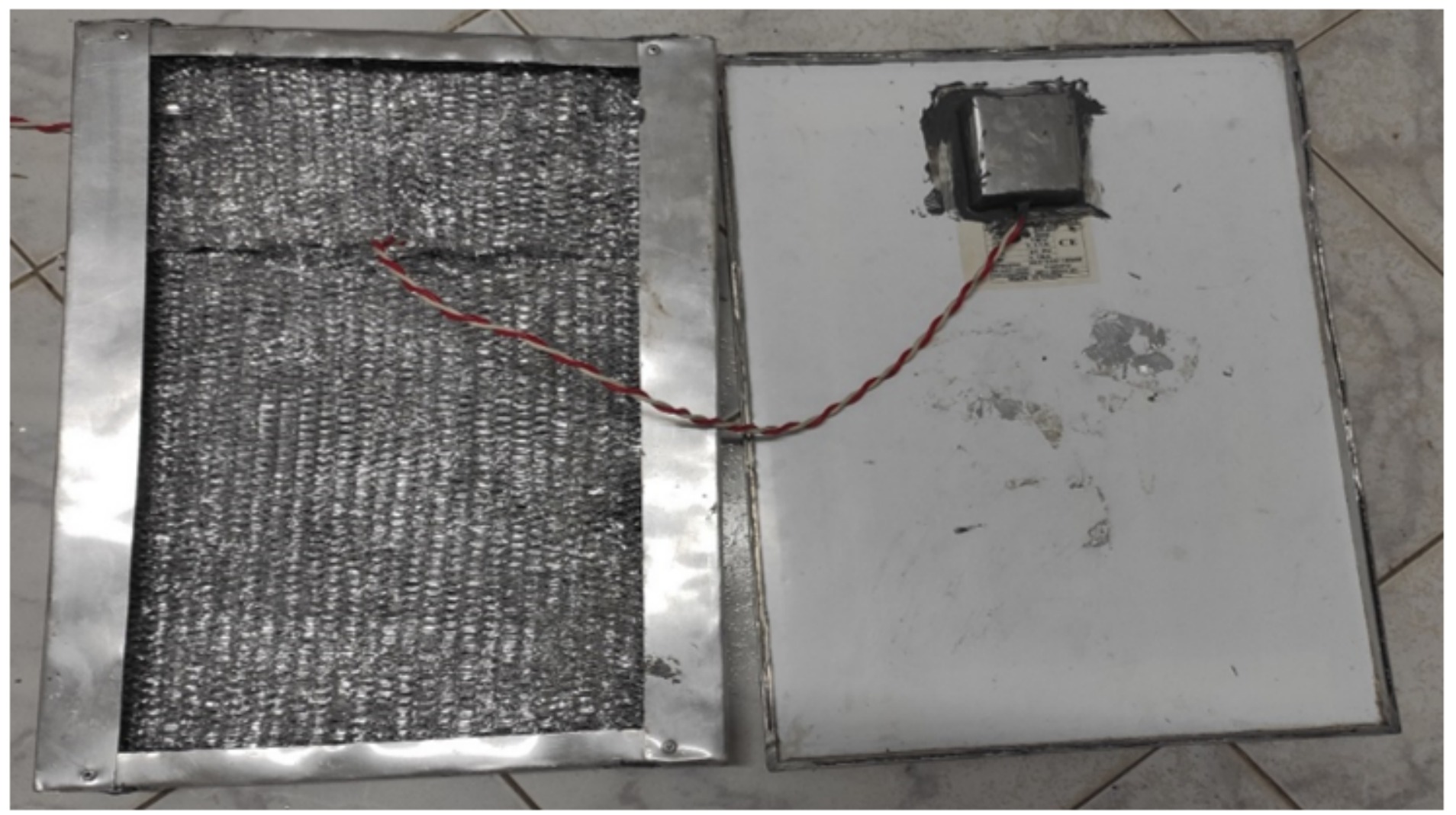

Figure 2 


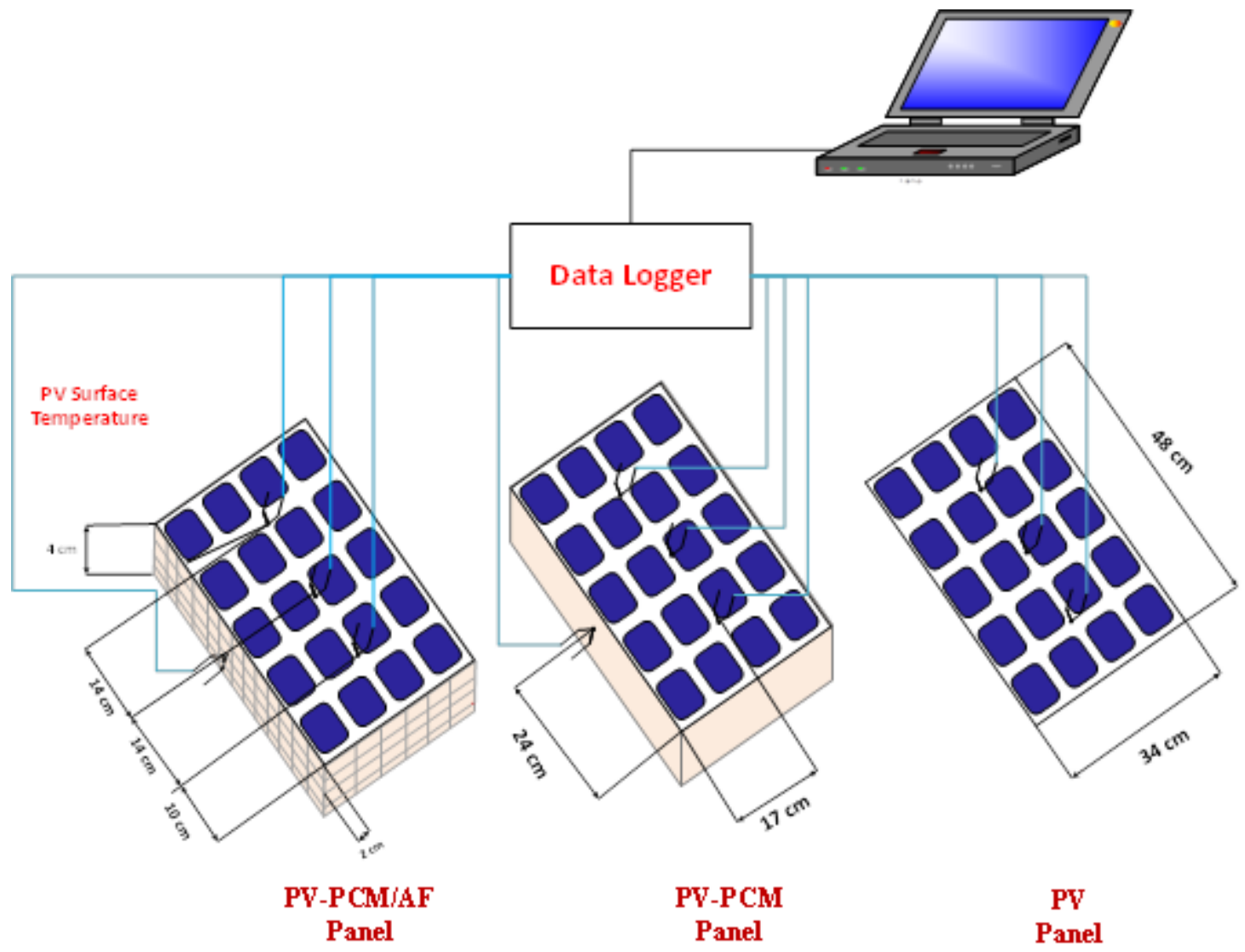

Figure 3

A schematic diagram of the proposed PV configurations 


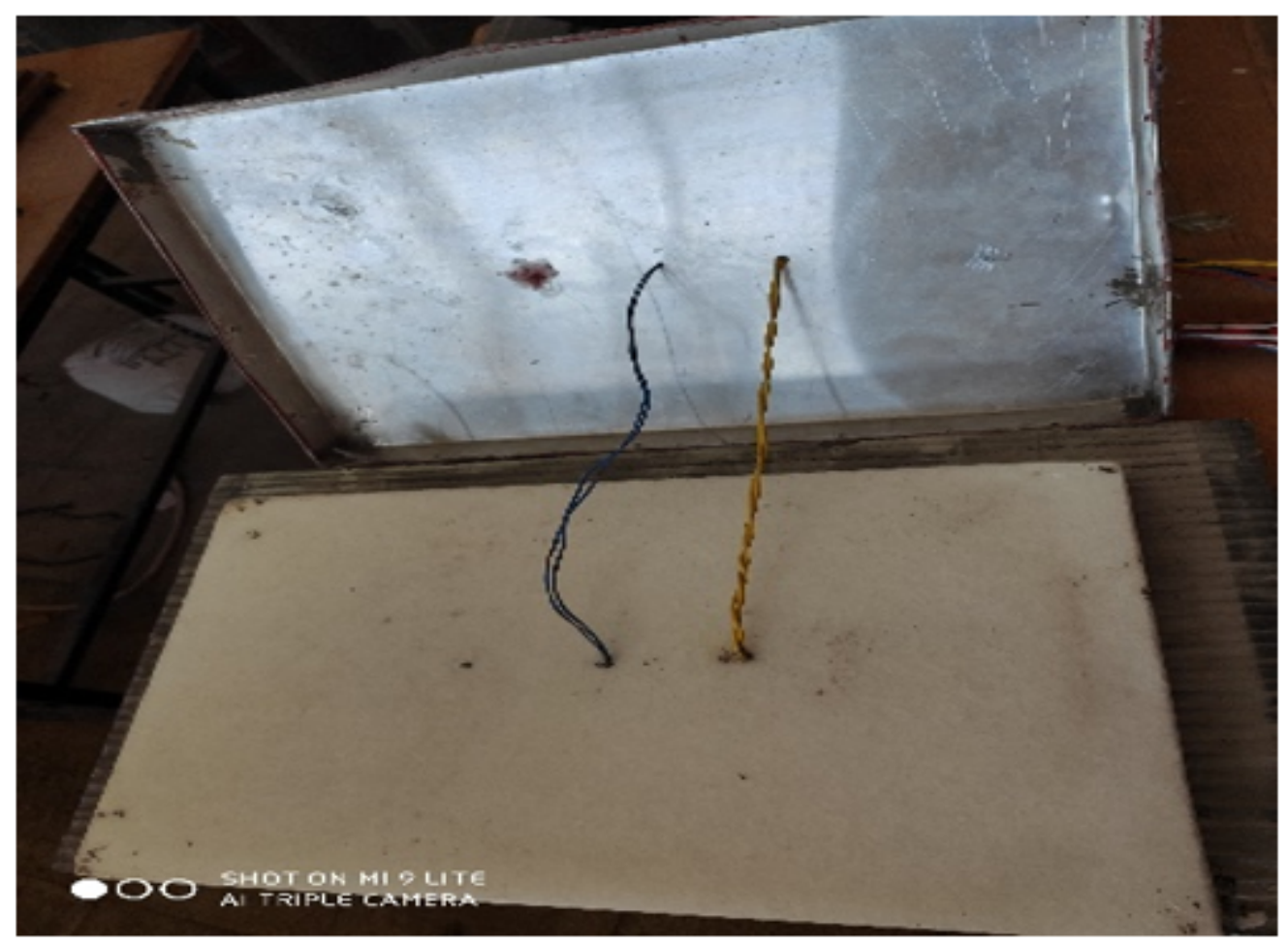

Figure 4

An image of PCM box

Figure 5

Solar intensity fluctuated during the experiment 


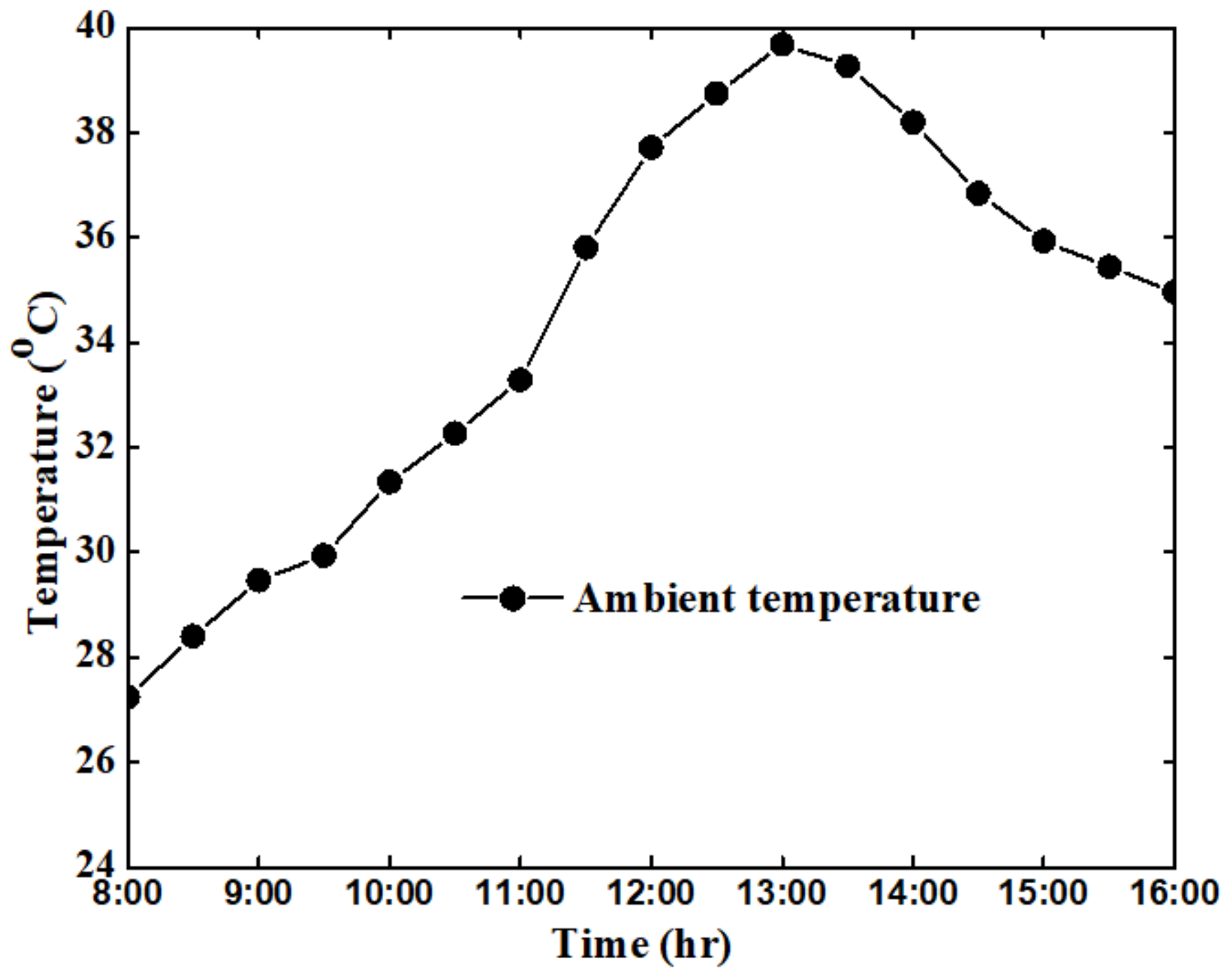

Figure 6

Ambient temperature fluctuated during the experiment. 


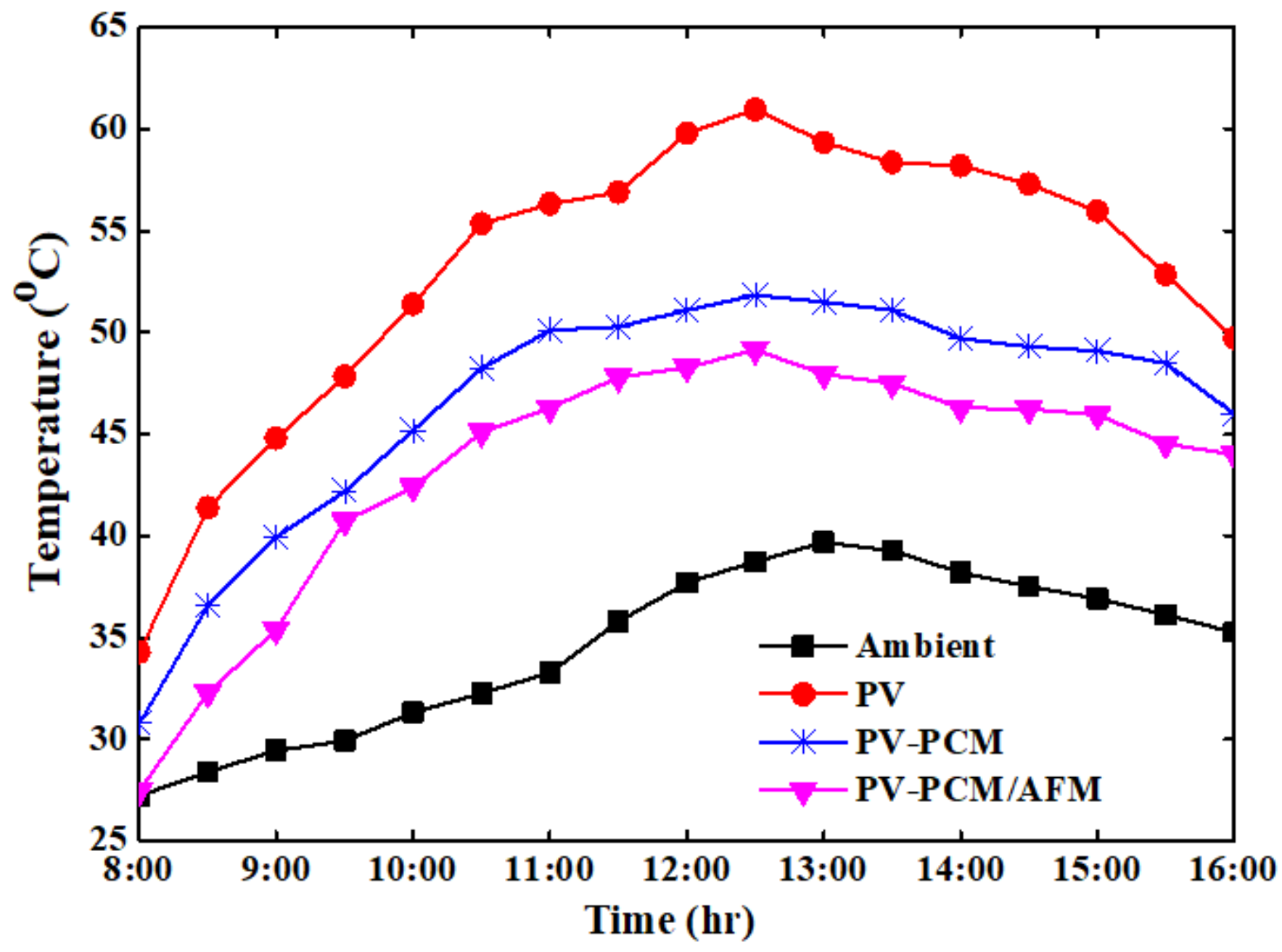

Figure 7

Surface temperature variations for all systems. 


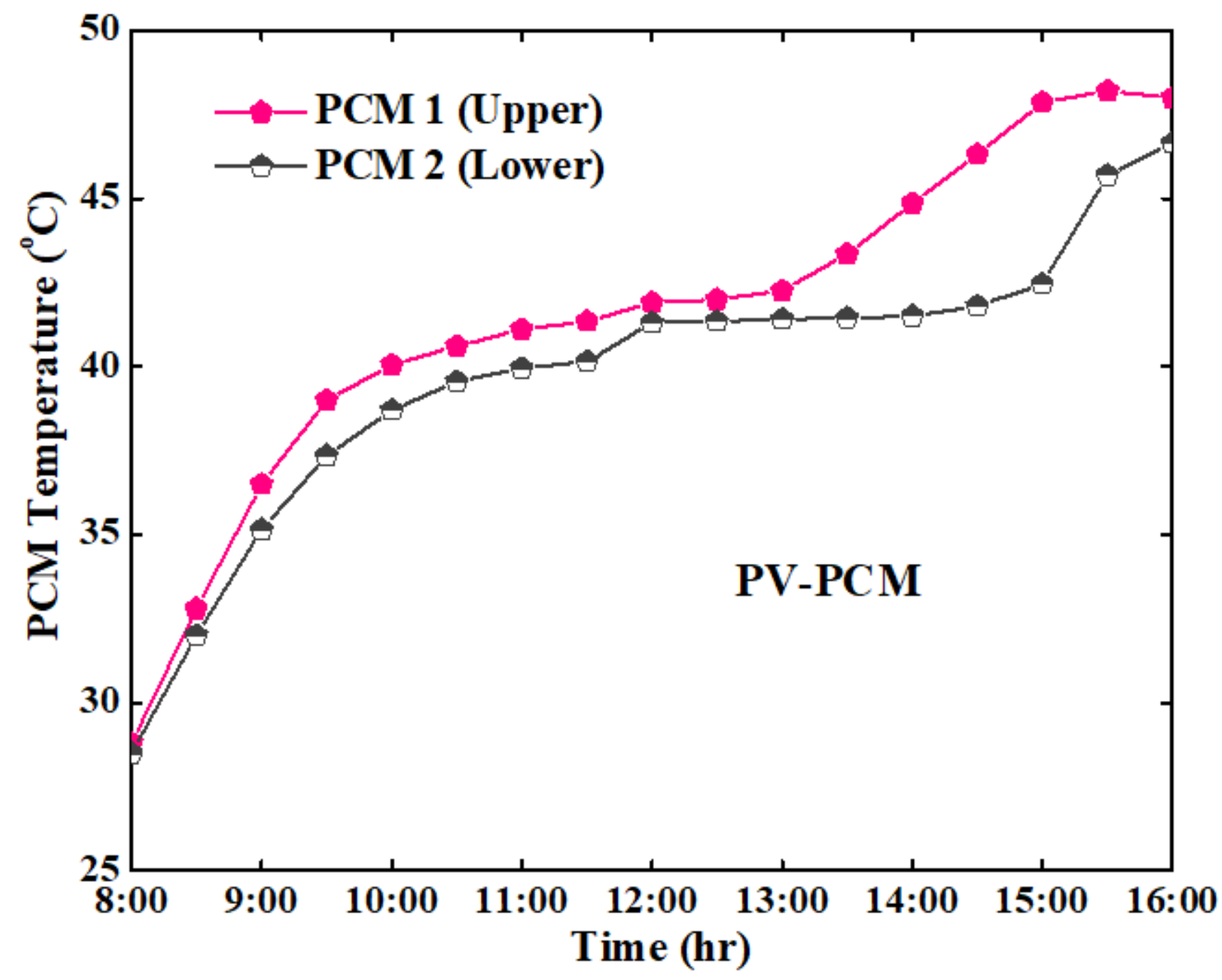

Figure 8

PCM temperature distribution inside PCM reservoir of PV-PCM system throughout the day 


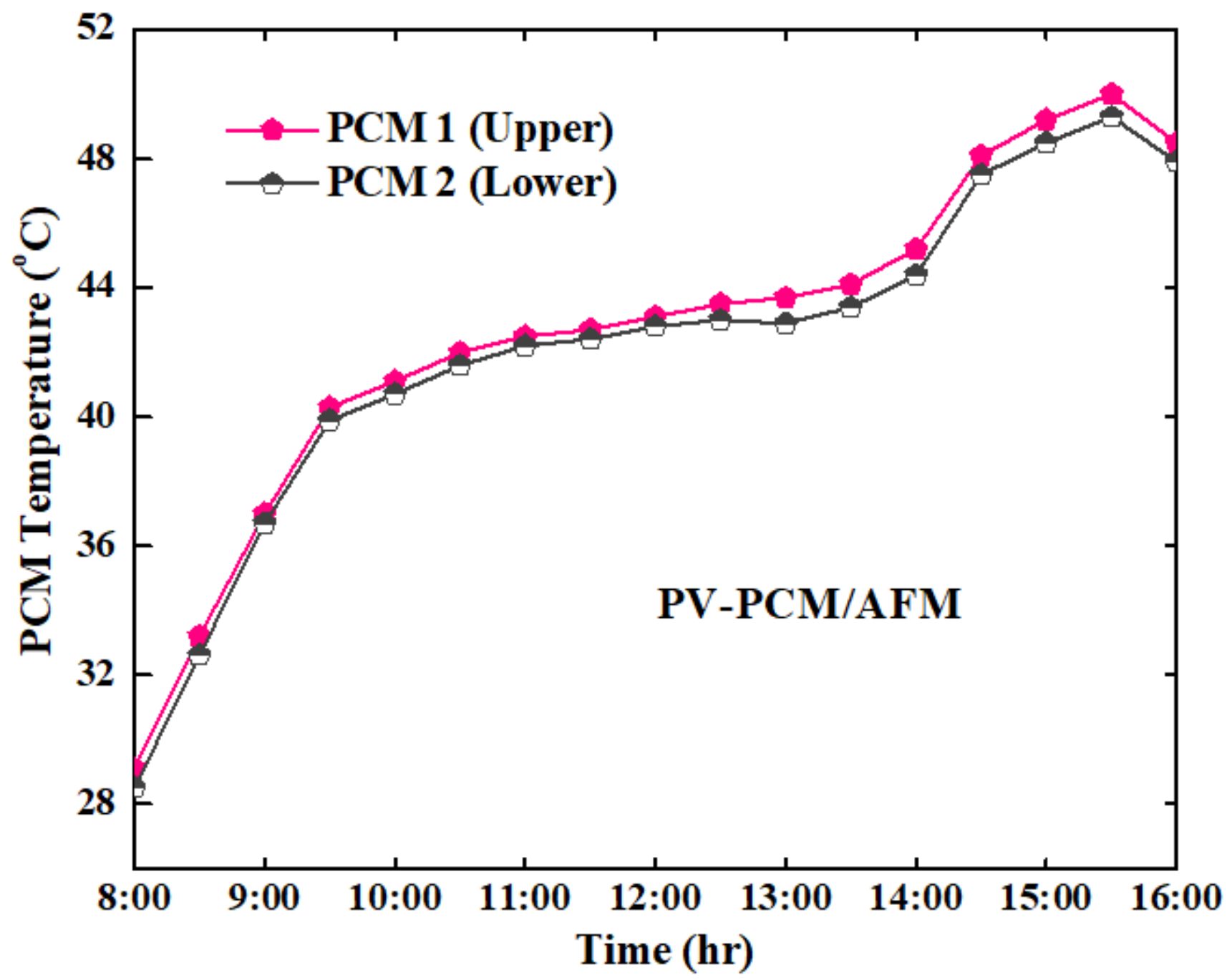

Figure 9

PCM temperature distribution inside PCM reservoir of PV-PCM/AFM system throughout the day 


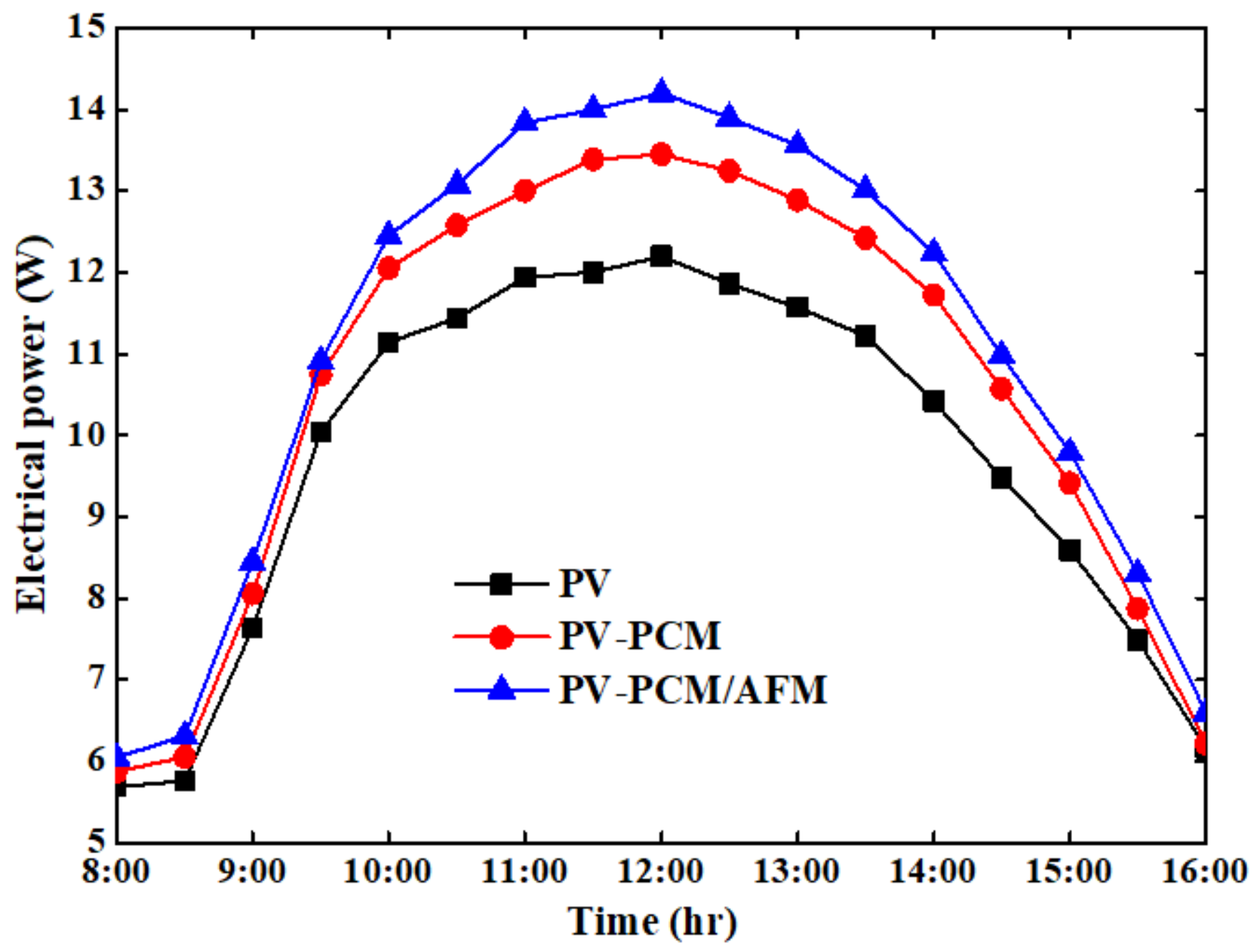

Figure 10

Variation of electrical power produced for all systems. 


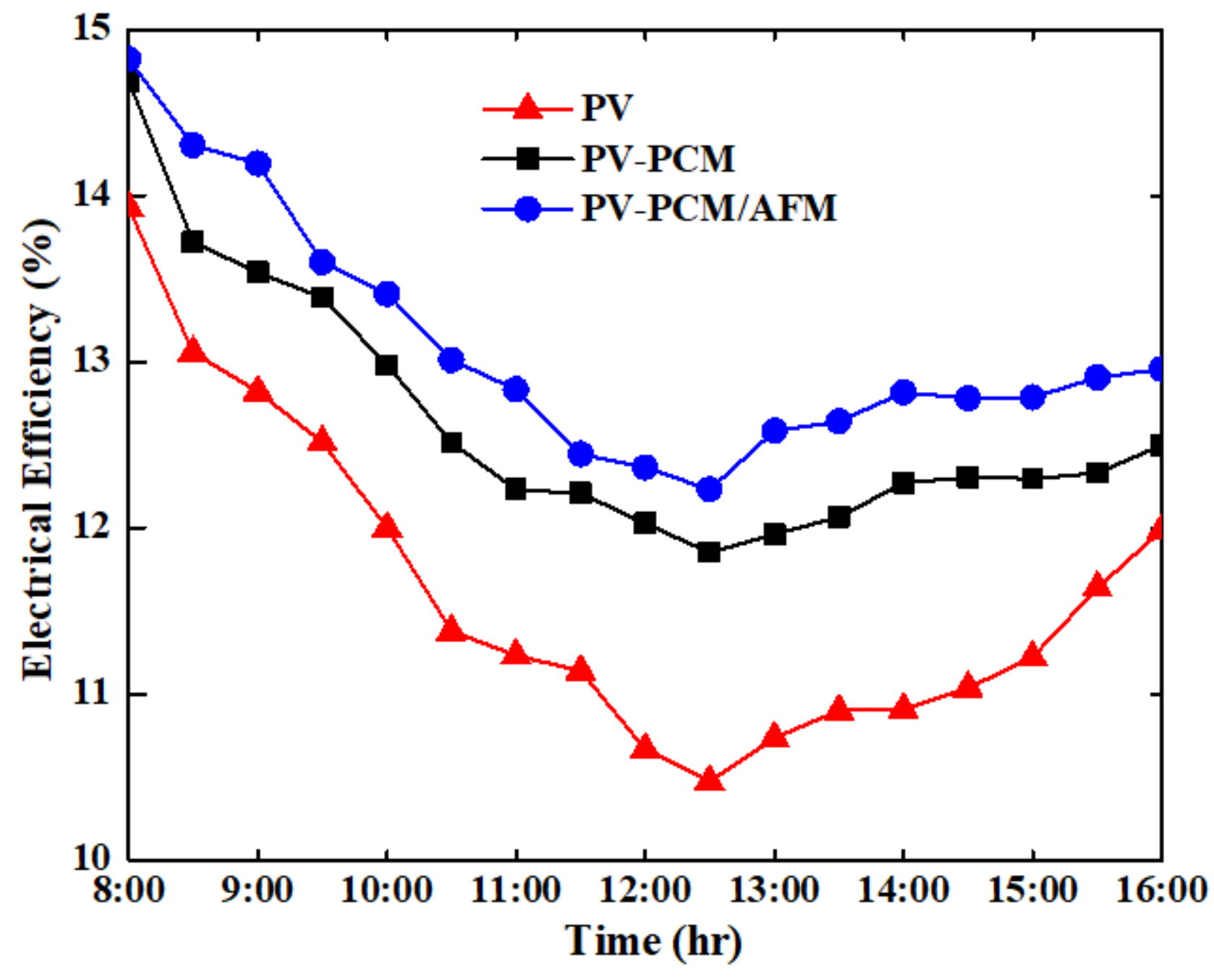

Figure 11

Variation of electrical efficiency for all systems. 